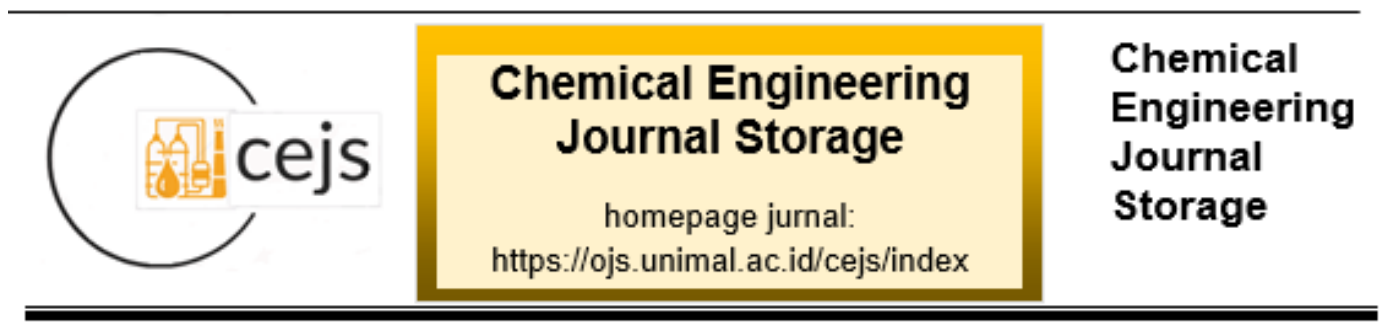

\title{
PEMANFAATAN TEPUNG GLUKOMANAN DARI PATI UMBI PORANG (AMORPHOPHALLUS MUELLERI BLUME) SEBAGAI BAHAN DASAR PEMBUATAN EDIBLE FILM
}

\author{
Zakenia Khairunnisa Falah, Suryati*, Novi Sylvia \\ Jurusan Teknik Kimia, Fakultas Teknik, Universitas Malikussaleh \\ Kampus Utama Cot Teungku Nie Reuleut, Muara Batu, Aceh Utara - 24355 \\ Korespondensi : 081269034134, e-mail: suryati@unimal.ac.id
}

\begin{abstract}
Abstrak
Bahan makanan pada umumnya sangat sensitif dan mudah mengalami penurunan kualitas. Bahan pengemas dari plastik banyak digunakan dengan pertimbangan ekonomis dan memberikan perlindungan yang baik dalam pengawetan. Penggunaan material sintetis tersebut berdampak pada pencemaran lingkungan, sehingga dibutuhkan penelitian mengenai bahan pengemas yang dapat diuraikan. Alternatif penggunaan kemasan yang dapat diuraikan adalah menggunakan edible film. Edible film didefinisikan sebagai lapisan yang dapat dimakan yang ditempatkan di atas atau di antara komponen makanan, dapat memberikan alternatif bahan pengemas yang tidak berdampak pada pencemaran lingkungan karena menggunakan bahan yang dapat diperbaharui dan harganya murah. Kandungan glukomanan pada umbi porang memiliki kemampuan membentuk lapisan film yang baik, biokompatibel yang baik, biodegradable serta memiliki kemampuan membentuk gel. Oleh karena itu umbi porang dapat dijadikan sebagai bahan dasar pembuatan biopolimer atau biodegradable polimer. Edible film Glukomanan dan plasticizer gliserol dengan penambahan kitosan dibuat dengan proses pemanasan pada suhu $50^{\circ} \mathrm{C}$ dan pengeringan pada suhu $60^{\circ} \mathrm{C}$. hasil terbaik edible film biodegradable diperoleh pada konsentrasi gliserol $3 \mathrm{ml}$ dan glukomanan 3 gram dan memiliki nilai ketebalan 0,59 mm, nilai ketahanan air 25,229\% dan nilai kemampuan terdegradasi 100\%. Hasil spektrum FTIR terhadap edible film menunjukkan tidak adanya perubahan bilangan gelombang dari spektrum glukomanan, kitosan dan gliserol dengan gugus fungsi $\mathrm{O}-\mathrm{H}, \mathrm{N}-\mathrm{H}$ dan $C=O$. Hal ini menunjukkan bahwa edible film yang dihasilkan hanya berinteraksi secara fisik.

Kata kunci: Edible film, Gliserol, Glukomanan, Kitosan, Umbi Porang
\end{abstract}

\section{Pendahuluan}

Penggunaan plastik di Indonesia sebagai bahan kemasan pangan untuk memenuhi keperluan sehari-hari sangat besar (mencapai 1,9 juta ton di tahun 2013), dikarenakan sifatnya yang fleksibel, ekonomis, kuat, tidak mudah pecah serta 
bersifat sebagai penahan yang baik bagi oksigen, uap air, dan karbondioksida. Disamping keunggulan tersebut, polimer plastik juga mempunyai berbagai kelemahan, yaitu plastik yang berasal dari minyak bumi jumlahnya semakin terbatas dan sifatnya yang tidak mudah didegradasi meskipun telah ditimbun puluhan tahun, akibatnya terjadi penumpukan limbah plastik yang menjadi penyebab pencemaran lingkungan. Seiring dengan kesadaran manusia akan masalah ini, maka dikembangkanlah jenis kemasan dari bahan organik yang berasal dari bahan-bahan terbarukan dan ekonomis, yaitu dengan mengembangkan plastik biodegradable dalam bentuk edible film yang dapat diuraikan kembali oleh mikroorganisme secara alami menjadi senyawa yang ramah lingkungan. Selain ramah lingkungan, pengembangan edible film pada kemasan pangan dapat memberikan kualitas produk yang lebih baik, karena terbuat dari bahan alami yang tidak beracun sehingga dapat langsung dimakan dan kecil kemungkinan terkena kontaminasi terhadap makanan.

Umbi Porang atau biasa disebut porang adalah salah satu jenis tanaman dari marga Amorphallus yang termasuk ke dalam suku talas-talasan (Araceae). Umbi ini mengandung glukomanan yang cukup tinggi (15 - 65\% basis kering) atau biasanya disebut dengan mannan yang merupakan polimer dari D-mannosa dan D-glukosa. Kandungan glukomanan pada umbi porang juga memiliki kemampuan membentuk lapisan film yang baik, biocompatibility yang baik, biodegradable serta memiliki kemampuan membentuk gel. Oleh karena itu umbi porang dapat dijadikan sebagai bahan dasar pembuatan biopolimer atau biodegradable polimer. Salah satu bahan yang dapat dijadikan bahan bioplastik dan mudah terurai ialah pati. Pati menjadi material yang sangat menjanjikan untuk bahan plastik karena sifatnya yang universal, dapat diperbaharui dan harganya terjangkau atau ekonomis (Ma, Chang, Yang \&Yu, 2009). Pati yang dihasilkan dari umbi porang yang mempunyai sifat biopolimer ini dapat dimanfaatkan dalam bidang industri sebagai bahan pembuatan edible film. Teknologi kemasan yang aman dan tidak merusak lingkungan sangat diperlukan, contohnya edible film (Mc Hugh et al., 1993).

Namun Tepung umbi porang mempunyai komponen hidrokoloid (glukomanan) yang kurang memiliki kemampuan untuk melindungi produk terhadap oksigen, karbondioksida dan lipid serta kurang memiliki sifat mekanis yang 
diinginkan seperti kurang elastis dan mudah sobek, maka perlu dilakukan penambahan plasticizer yang berfungsi untuk meningkatkan elastisitas, mengurangi resiko pecah, sobek dan hancurnya edible film yang terbentuk.

Berdasarkan uraian diatas, maka penulis ingin melakukan penelitian mengenai "Pemanfaatan tepung glukomanan dari pati umbi porang (amorphophallus muelleri blume) sebagai bahan dasar pembuatan Edible film".

\section{Bahan dan Metode}

Peralatan yang diperlukan pada penelitian ini antara lain oven, seperangkat alat spektrofotometer, blender, cetakan kaca, gelas ukur, spatula, neraca analitik, corong, beaker gelas dan erlenmeyer. Bahan yang digunakan yaitu kitosan, tepung glukomanan, gliserol, aqua destilat dan asam asetat $1 \%$.Penelitian ini terdiri dari tiga tahap yaitu persiapan bahan baku, pengolahan biopolimer dan proses analisa.

Pada tahap persiapan bahan baku, kitosan 2 gram dilarutkan dalam $100 \mathrm{ml}$ asam asetat $1 \%$ menggunakan blender.

Kemudian pada tahap pengolahan biopolimer variasi tepung glukomanan, dan gliserol, ditimbang glukomanan sebanyak 3 gr, 4 gr, 5 gr dan 6 gr yang kemudian dimasukkan kedalam masing - masing 5 erlenmeyer, lalu menambahkan seluruh Erlenmeyer dengan $100 \mathrm{ml}$ aqua distilat dan selanjutnya dipanaskan diatas hot plate stirrer dengan suhu $50^{\circ} \mathrm{C}$ selama 15 menit.

Kemudian larutan kitosan perlahan - lahan dimasukkan kedalam campuran sebanyak $10 \mathrm{ml}$ dan masukkan plasticizer gliserol sebanyak $2 \mathrm{ml}, 3 \mathrm{ml}, 4 \mathrm{ml}, 5 \mathrm{ml}$ dan $6 \mathrm{ml}$ kedalam Erlenmeyer yang berisi glukomanan dan dipanaskan kembali pada hot plate stirrer dengan suhu $50^{\circ} \mathrm{C}$ selama 15 menit.

Selanjutnya larutan didinginkan hingga mencapai suhu ruangan selama 24 jam untuk menghilangkan gelembung udara. Kemudian larutan yang sudah didinginkan dimasukkan kedalam plat kaca yang sudah disediakan dengan ketebalan yang sama dan dikeringkan dalam oven selama 24 jam pada suhu $60^{\circ} \mathrm{C}$. Setelah dikeirngkan, diangkat dan dimasukkan ke dalam desikator selama 24 jam lalu edible film dilepas dari cetakan plat kacanya. 
Pada tahap ketiga yaitu proses analisa, analisa biopolimer dilakukan dengan beberapa parameter yang diamati diantara nya analisa ketebalan, analisa ketahanan air, analisa biodegradasi, analisa kuat tarik dan analisa gugus fungsi

Penentuan ketebalan biopolimer menggunakan mikrometer sekrup. Penentuan ketebalan dapat dihitung dengan menggunakan persamaan 1.

Ketebalan $=\mathrm{Su}+(\mathrm{Sn} \times 0,01)$

Dimana:

$\mathrm{Su}=$ Skala utama $(\mathrm{mm})$

$\mathrm{Sn}=$ Skala nonius $(\mathrm{mm})$

Perhitungan analisa ketahanan air dapat dihitung menggunakan persamaan 2.

$\%$ Ketahanan Air $=\frac{\mathrm{W}-\mathrm{W} 0}{\mathrm{~W}} \times 100 \%$

Dimana :

$\mathrm{W}=$ massa edible film setelah dimasukkan kedalam air (gram)

$\mathrm{W}_{0}=$ berat massa edible film sebelum dimasukkan kedalam air (gram)

Perhitungan analisa biodegradasi dapat dihitung menggunakan persamaan 3.

$\%$ Biodegradiabilitas $=\frac{\text { Mo }- \text { M1 }}{\text { MO }} \times 100 \%$

Dimana :

$\mathbf{M}_{0}=$ massa sampel awal (gram)

$\mathrm{M}_{1}=$ massa sampel akhir (gram)

Pada analisa kuat tarik, sampel yang akan diuji dilakukan dengan menggunakan alat mechanical universal testing machine ASTM-D-638 dengan ukuran tipe IV. Biopolymer yang diuji dengan ASTM-D-638 akan menghasilkan grafik yang menggambarkan nilai Stress at Break.

Pada uji gugus fungsi, bahan yang akan diuji dilarutkan dengan $\mathrm{KBr}$ yang kemudian diuji dengan alat FTIR. Biopolimer yang diuji dengan spektroskopi FTIR akan menghasilkan grafik spektrum yang menggambarkan nilai bilangan gelombang dan $\%$ transmitansi. 


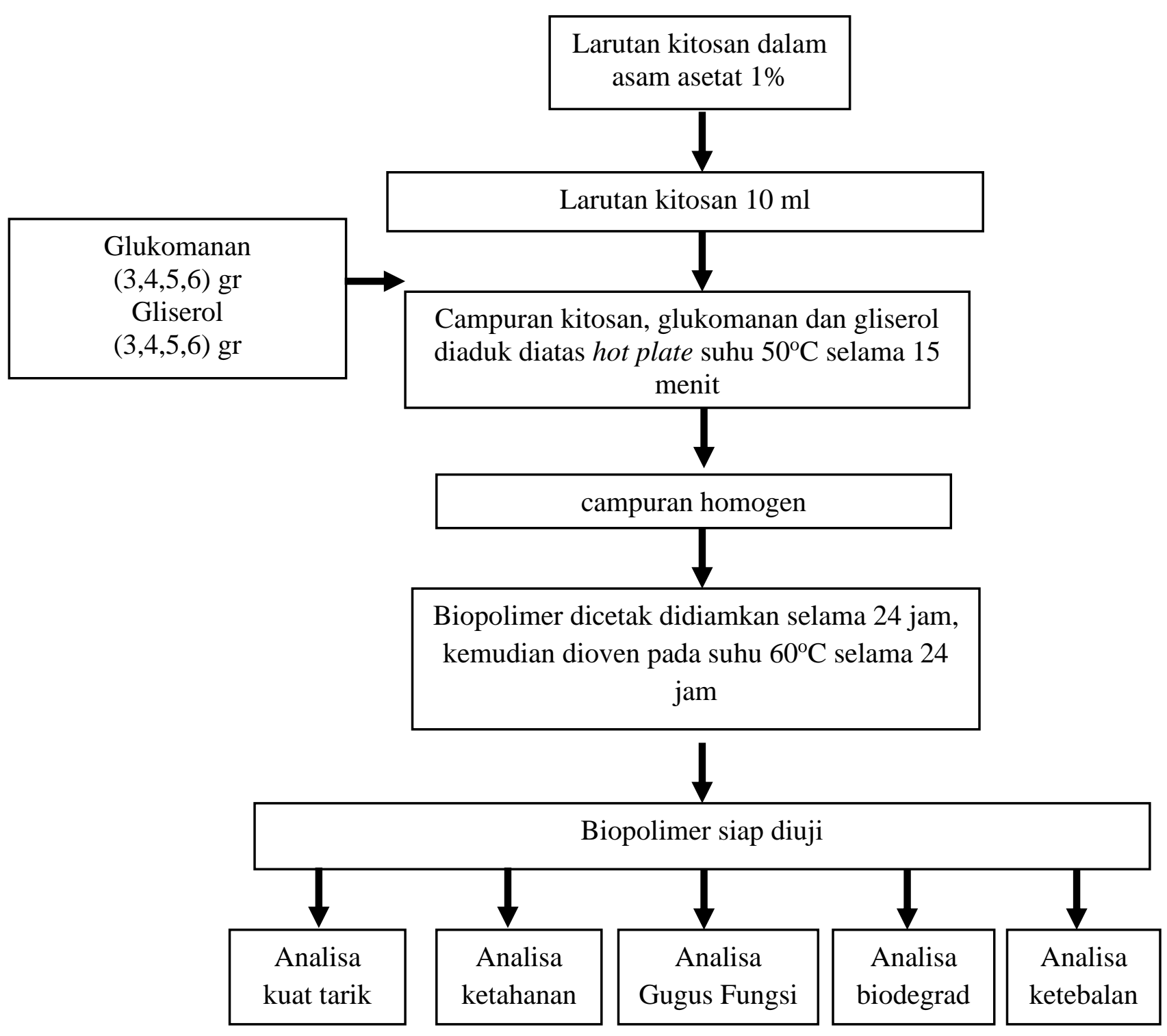

Gambar 2.1. Blok Diagram Pembuatan Edible Film dan Proses Analisa

\section{Hasil dan Diskusi}

\subsection{Edible film pada Analisa Ketebalan}

Pada proses uji ketebalan film bioplastik digunakan alat micrometer secrup dengan cara mengukur lima titik pada bagian film bioplastic dan nilai ketebalan yang didapatkan adalah hasil rata - rata dari nilai lima titik tersebut. Nilai ketebalan bioplastik bergantung pada jumlah konsentrasi padatan yang larut. Menurut (Melani et al., 2017) semakin tinggi konsentrasi padatan yang terlarut pada larutan maka film 
bioplastic yang dihasilkan juga akan semakin tebal. Pengukuran ini dilakukan dengan mengambil sampel edible film dari 5 sisi yang berbeda. Adapun pengaruh komposisi bahan terhadap ketebalan dapat dilihat pada Gambar 3.1.

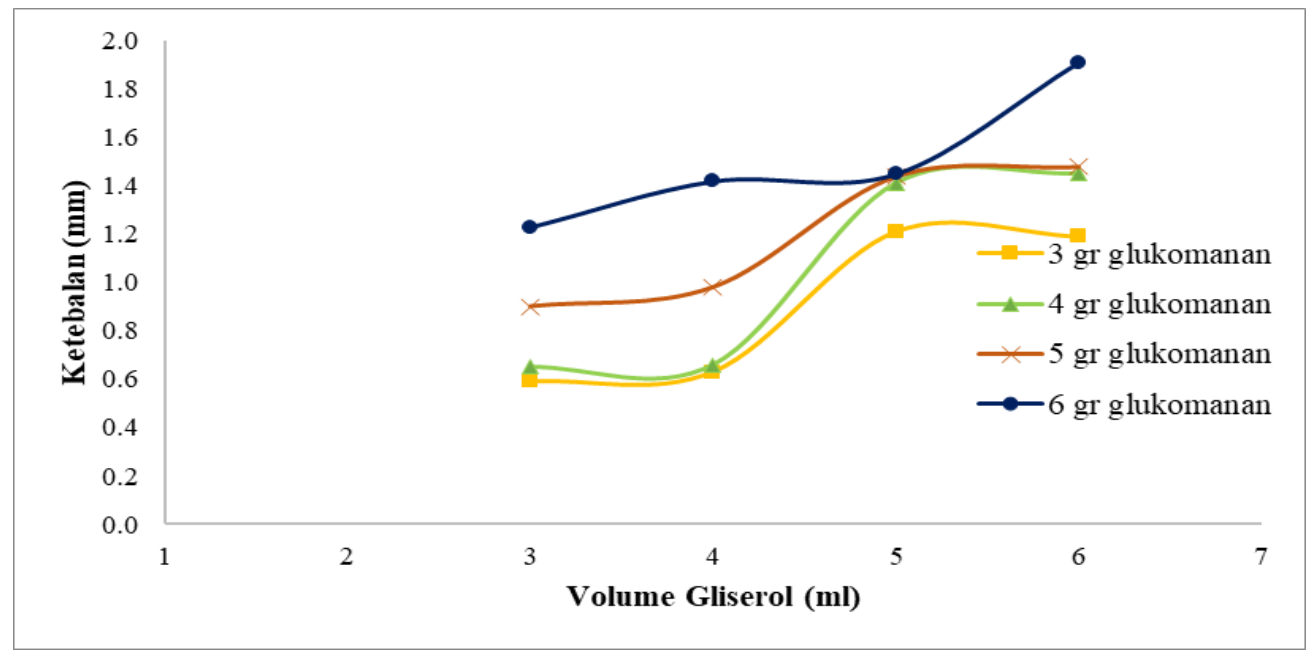

Gambar 3.1. Grafik hubungan volume gliserol terhadap ketebalan Edible Film dan massa glukomanan.

Berdasarkan Gambar 3.1 menunjukkan bahwa nilai rata-rata ketebalan edible film yang diperoleh berkisar antara 0,59-1,91 mm. Ketebalan edible film terendah diperoleh oleh volume gliserol $3 \mathrm{ml}$ dan 3 gram glukomanan yaitu 0,59 mm, sedangkan ketebalan edible film tertinggi diperoleh oleh volume gliserol $6 \mathrm{ml}$ dan 6 gram glukomanan yaitu $1,91 \mathrm{~mm}$. Hal ini menunjukkan bahwa penambahan glukomanan berturut - turut akan mengalami peningkatan serta menunjukkan bahwa penambahan gliserol berbanding lurus dengan ketebalan edible film yang diperoleh. Sehingga semakin tinggi konsentrasi penambahan gliserol dan ekstrak glukomanan dari tepung porang akan meningkatkan ketebalan edible film. Hal ini berkaitan dengan semakin tingginya konsentrasi komponen penyusun film maka akan meningkatkan total padatan sehingga meningkatkan ketebalan edible film. Peningkatan konsentrasi bahan yang digunakan dalam pembuatan film akan meningkatkan total padatan yang terdapat dalam edible film. 


\subsection{Edible Film Pada Analisa Ketahanan Air}

Pada pengujian ketahanan air edible film dilakukan dengan cara merendam edible film selama 5 menit didapatkan berat yang konstan. Nilai persentase ketahanan air didapatkan dari nilai berat edible film sebelum direndam dan setelah direndam. Menurut (Coniwanti et al., 2014) sifat ketahanan air edible film ditentukan dengan seberapa banyak menyerap air atau persentase penggembungan edible film dengan adanya air yang masuk. Persentase ketahanan air dipengaruhi oleh penambahan kitosan, penambahan gliserol dan ketebalan edible film. Menurut (Darni et al., 2014) penambahan kitosan dapat meningkatkan persentase ketahanan air pada edible film, hal ini terjadi karena kitosan merupakan senyawa yang tidak suka dengan air (hidrofobik) dan tidak larut dalam air. Tetapi dalam hal ini kitosan tidak dapat sepenuhnya merubah sifat fisik edible film menjadi hidrofobik. Adapun pengaruh komposisi bahan terhadap \% ketahanan air dapat dilihat pada Gambar 3.2.

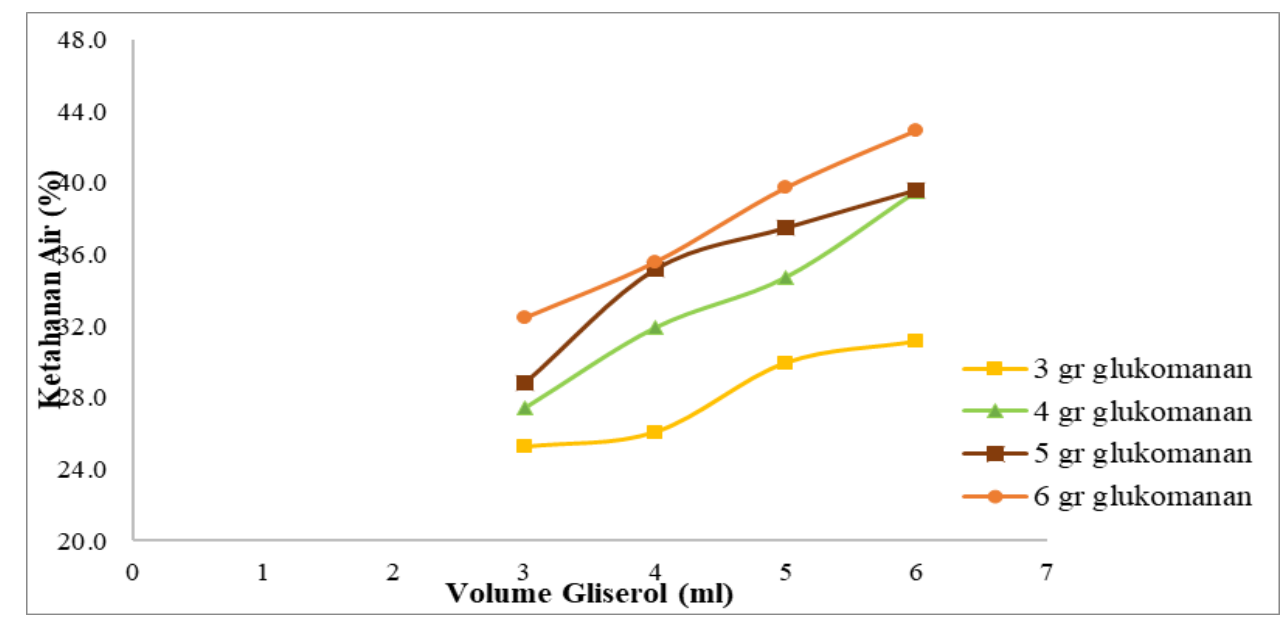

Gambar 3.2 Grafik hubungan volume gliserol terhadap persen ketahanan air Edible Film dan massa glukomanan.

Berdasarkan Gambar 3.2 menunjukkan bahwa nilai rata-rata persentase ketahanan air berkisar antara 25,229\% - 42,904\%. Persentase ketahanan air terendah diperoleh pada variasi $3 \mathrm{ml}$ gliserol dan 3 gram tepung glukomanan, sedangkan persentase ketahanan air tertinggi diperoleh pada variasi $6 \mathrm{ml}$ gliserol dan 6 gram tepung glukomanan.

Hasil yang diperoleh menunjukkan bahwa penambahan glukomanan dan gliserol berturut-turut akan mengalami peningkatan terhadap edible film yang 
diperoleh. Hal ini dikarenakan glukomanan memiliki sifat hidrofilik sehingga kelarutan air semakin besar. Sedangkan untuk gliserol, semakin besar konsentrasi gliserol maka daya larut film terhadap air semakin besar karena aktivitas interaksi antar molekul menurun. Sehingga kemampuan edible film dalam menahan air berkurang. Peningkatan jumlah komponen yang bersifat hidrofilik, yaitu glukomanan dalam edible film, diduga yang menyebabkan tingginya persentase ketahanan air. Ketika kemampuan menahan air berkurang maka dapat diartikan bahwa edible film memiliki kelarutan yang tinggi dalam air. Edible film dengan daya larut yang tinggi cocok digunakan untuk produk pangan siap makan karena saat dikonsumsi akan mudah larut.

\subsection{Edible Film Pada Analisa Biodegradable}

Pengujian daya biodegradabilitas ini dilakukan untuk mengetahui daya urai film plastik oleh mikroorganisme dalam tanah. Pengujian ini dilakukan dengan menggunakan metode Soil Burial Test, yakni dengan mengubur sampel ke dalam tanah kemudian diamati berat sampel sebelum dan sesudah dikubur. Adapun pengaruh komposisi bahan terhadap \% biodegradasi dapat dilihat pada Gambar 3.3.

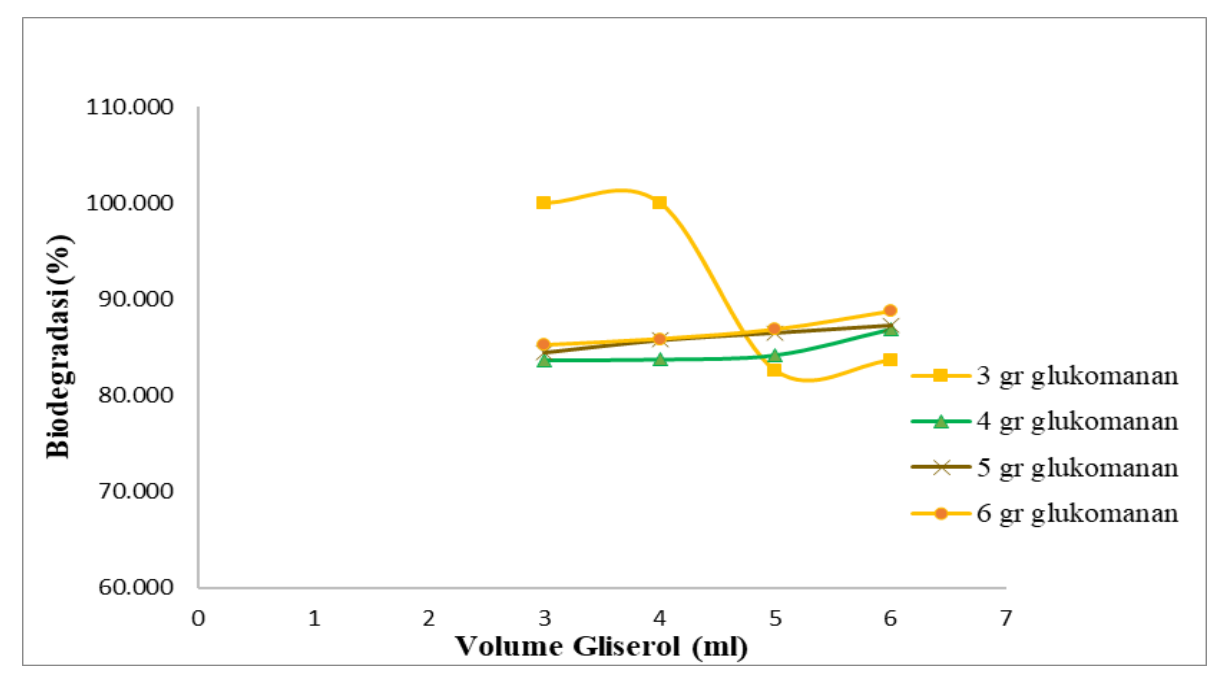

Gambar 3.3 Grafik hubungan volume gliserol terhadap persen biodegradasi Edible Film dan massa glukomanan.

Berdasarkan hasil analisa yang ditunjukkan pada Gambar 3.3 dapat diketahui bahwa daya biodegradabilitas tertinggi yaitu pada perlakuan dengan formulasi $3 \mathrm{ml}$ gliserol dengan 3 gram dan 4 gram glukomanan. Nilai biodegradabilitas terendah ada 
pada film dengan variasi $3 \mathrm{ml}$ gliserol dengan 5 gram glukomanan. Pada Gambar 3.3 mengartikan bahwa film dengan perbandingan gliserol dan glukomanan yang rendah membutuhkan waktu yang lama untuk terdegradasi dalam tanah dibandingkan perbandingan gliserol dan glukomanan yang tinggi. Namun terdapat pengecualian pada formulasi $3 \mathrm{ml}$ gliserol dengan 3 gram dan 4 gram glukomanan, hal ini dikarenakan bentuk fisik dari edible film yang tipis sehingga memudahkan mikroorganisme untuk mengurai film dalam waktu yang singkat. Menurut (Utami \& Widiarti, 2014) bioplastik mudah terdegradasi karena bioplastik yang dihasilkan mengandung gugus hidroksil $(\mathrm{OH})$ dan gugus karbonil $(\mathrm{CO})$. Gugus tersebut memiliki sifat hidrofilik sehingga molekul air dapat mengakibatkan mikroorganisme pada lingkungan memasuki matriks plastik tersebut. Tanah sebagai media tumbuh sebagian besar bakteri dan mikroba, sehingga akan mengakibatkan bioplastik menjadi lebih mudah terdegradasi.

\subsection{Edible Film Pada Analisa Kuat Tarik}

Menurut (Yu et al., 2018) kuat tarik atau tensile strength merupakan suatu gaya tarik maksimum yang diberikan pada suatu sampel edible film hingga sampel edible film tersebut terputus. Pengujian nilai kuat tarik edible film menggunakan alatZwick/Roell, edible film dipotong berdasarkan ASTM D638 yang merupakan standarisasi pengujian polimer. Nilai kuat tarik yang dihasilkan pada film bioplastic dipengaruji oleh penambahan konsentrasi kitosan serta gliserol sebagai bahan pendukung pembuatan edible film. Menurut (Darni et al., 2014) sifat mekanik ditentukan oleh kerapatan suatu bahan, dimana bahan yang lebih rapat sifat mekaniknya semakin bagus dan nilai kuat tarik yang akan dihasilkan semakin baik. Hal ini juga disampaikan oleh (Rahmadani, 2019) bahwa kenaikan nilai kuat tarik juga dapat disebabkan oleh kandungan air yang sedikit pada sampel edible film tersebut sehingga struktur molekul pada edible film tersebut menjadi lebih rapat. Adapun pengaruh komposisi bahan terhadap \% kuat tarik dapat dilihat pada gambar 3.4 . 


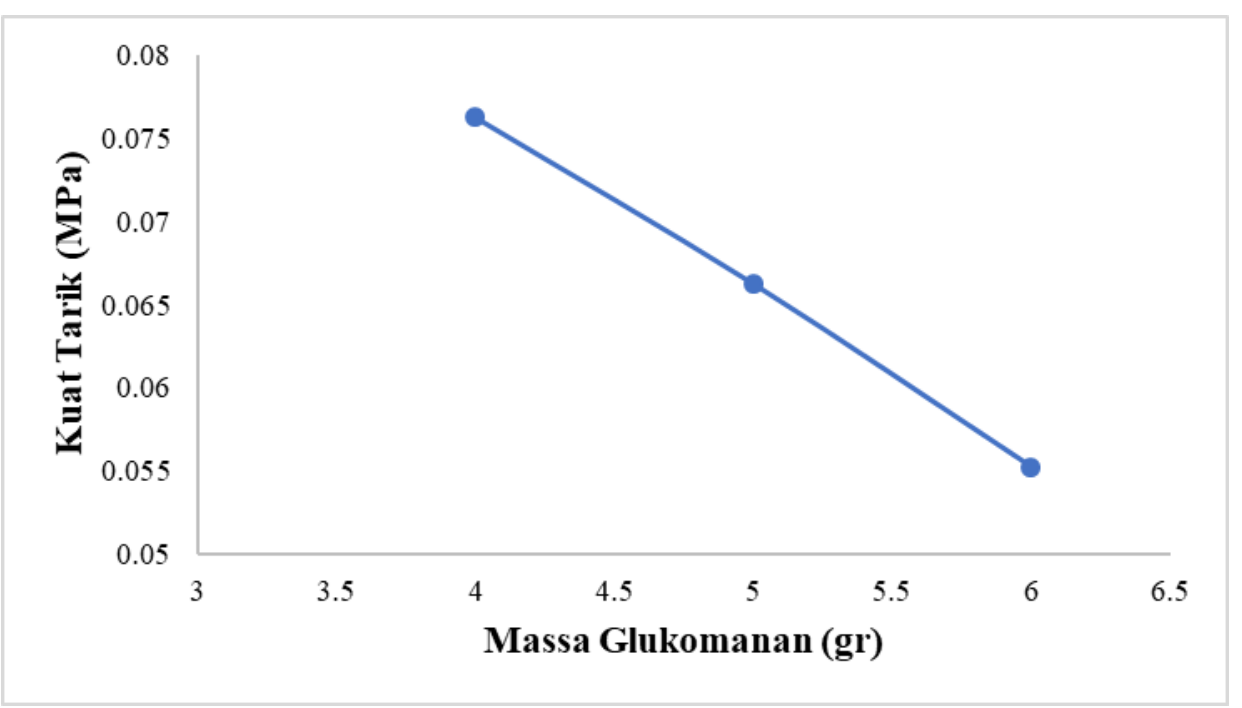

Gambar 3.4 Grafik hubungan massa glukomanan terhadap sifat kuat tarik Edible Film

Hasil uji kuat tarik yang didapatkan dapat dilihat pada Gambar 3.4 yang menunjukkan nilai kuat tarik edible film. Sampel yang digunakan pada uji kuat tarik yaitu penggunaan $6 \mathrm{ml}$ gliserol dengan 4 gr, 5 gr dan 6 gr tepung glukomanan. Pemilihan variasi ini dilakukan karena melihat sifat fisik dari edible film yang dibentuk berupa ketebalan. Berdasarkan Gambar 3.4 dapat dilihat bahwa persentase kuat tarik edible film dengan penambahan gliserol dan tepung glukomanan berturut turut yaitu gliserol $6 \mathrm{ml}$ dan glukomanan 4 gram adalah 0,1525 MPa, gliserol $6 \mathrm{ml}$ dan glukomanan 5 gram adalah 0,1325 MPa serta gliserol $6 \mathrm{ml}$ dan glukomanan 6 gram adalah 0,1105 $\mathrm{MPa}$.

Secara teori menjelaskan bahwa penambahan gliserol terhadap pembuatan edible film mengakibatkan adanya penurunan kuat tarik. Kenaikan jumlah plasticizer menurunkan tensile strength, dikarenakan penambahan plasticizer menurunkan gaya antar molekul dari bahan penyusun polimer, sehingga polimer menjadi lentur dan tidak kaku.

\subsection{Analisa Gugus Fungsi}

Analisa gugus fungsi (FTIR) bertujuan untuk mengidentifikasi senyawa, khususnya senyawa organik baik secra kualitatif maupun kuantitatif. Analisis dilakukan dengan melihat bentuk spektrumnya yaitu melihat puncak-puncak spesifik 
yang menunjukkan gugus fungsional yang dimiliki oleh senyawa tersebut. Adapun analisa gugus fungsi (FTIR) dapat dilihat pada Gambar 3.5.

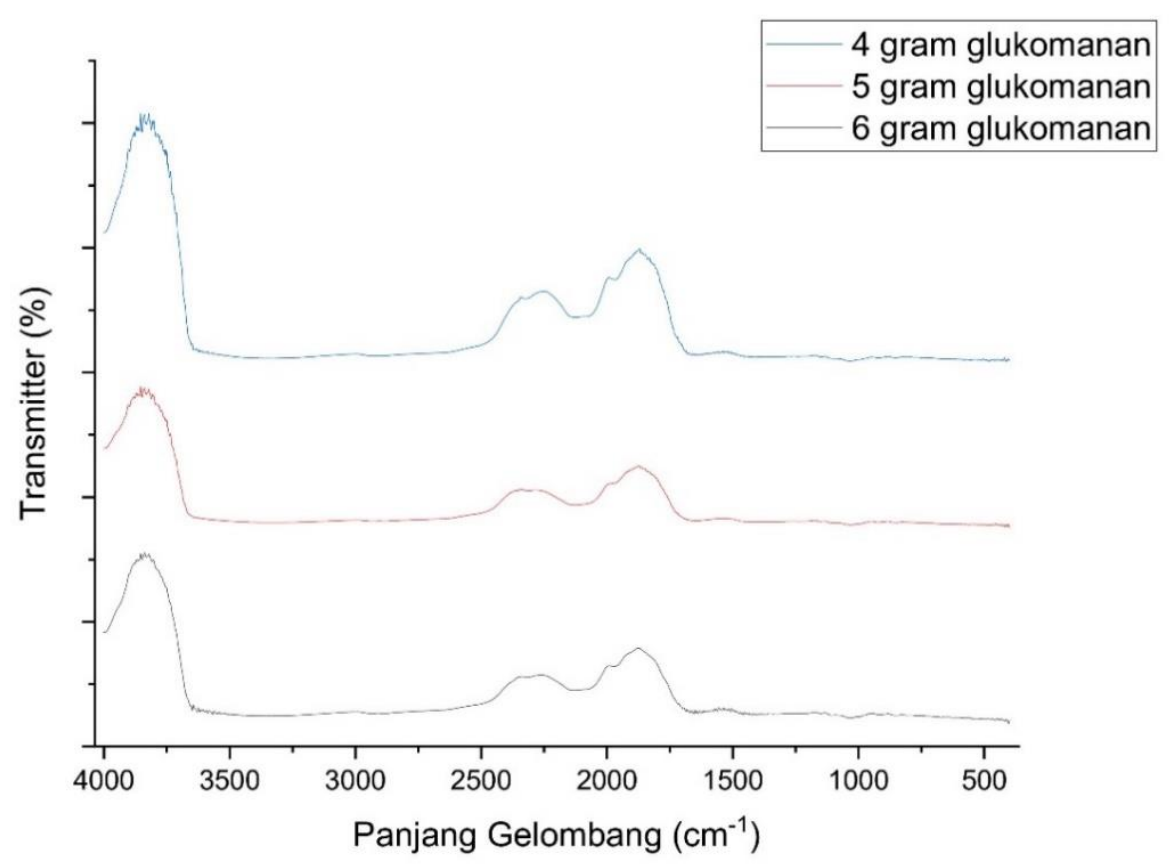

Gambar 3.5 Grafik FTIR Edible Film Tepung Glukomanan

Gambar 3.5 menunjukkan gugus fungsi dan senyawa yang terbentuk pada lapisan film. Dari ke tiga sampel yang diuji yaitu gliserol $6 \mathrm{ml}$ dengan variasi glukomanan 4 gram, 5 gram dan 6 gram hasil analisis FTIR untuk mengetahui gugus fungsi berdasarkan panjang gelombang yang terlihat bahwa pita serapan ikatan $\mathrm{O}-\mathrm{H}$ dengan nama senyawa alcohol dan fenol berada pada bilangan gelombang 3838,34 $\mathrm{cm}^{-1}$. Gugus $\mathrm{O}-\mathrm{H}$ yang terbentuk menunjukkan adanya penambahan konsentrasi gliserol yang digunakan yang berikatan pada gugus $\mathrm{OH}$ pada glukomanan. Ikatan rangkap dua dengan gugus fungsi $\mathrm{C}=\mathrm{O}$ teridentifikasi pada bilangan gelombang 1969,32 $\mathrm{cm}^{-1}$ yang merupakan struktur karbohidrat pada pati. Ikatan tunggal nitrogen, karbon dan hydrogen pada gugus $\mathrm{N}-\mathrm{H}$ dan $\mathrm{C}-\mathrm{H}$ teridentifikasi pada bilangan gelombang $2316,51 \mathrm{~cm}^{-1}, 2314,58 \mathrm{~cm}^{-1}$ dan $2322,29 \mathrm{~cm}^{-1}$. Ikatan $\mathrm{N}-\mathrm{H}$ merupakan gugus pada senyawa penyusun kitosan, sedangkan ikatan $\mathrm{C}-\mathrm{H}$ merupakan identifikasi adanya gugus aldehid. Gugus aldehid terdeteksi di dalam pati, dimana gugus aldehid merupakan salah satu gugus penyusun glukosa. Glukosa 
merupakan struktur dasar dari pembentukan 1 molekul amilosa dan amilopektin membentuk amilum dan pati.

\section{Simpulan dan Saran}

Kesimpulan yang dapat diambil dari penelitian ini yaitu pada uji ketebalan, edible film berbahan dasar tepung glukomanan, gliserol dan kitosan sebesar 1,91 mm. Untuk hasil pada analisa ketahanan air, edible film berbahan dasar tepung glukomanan, gliserol dan kitosan sebesar yaitu pada variasi komposisi $3 \mathrm{ml}$ gliserol dan 3 gram glukomanan yaitu sebesar 25,229\%. Pada analisa biodegradable, edible film berbahan dasar tepung glukomanan, gliserol dan kitosan sebesar yaitu pada variasi komposisi $3 \mathrm{ml}$ gliserol dan 3 gram glukomanan yaitu sebesar 100\%. Pada analisa kuat tarik, edible film berbahan dasar tepung glukomanan, gliserol dan kitosan sebesar yaitu pada variasi komposisi $6 \mathrm{ml}$ gliserol dan 4 gram glukomanan yaitu sebesar 0,1525 $\mathrm{mPa}$. Kemudian untuk analisa gugus fungsi (FTIR) dihasilkan gugus fungsi $\mathrm{O}-\mathrm{H}, \mathrm{N}-\mathrm{H}$ dan gugus fungsi $\mathrm{C}=\mathrm{O}$ yang menunjukkan bahwa edible film cenderung bersifat hidrofilik, adapun gugus fungsi tersebut menunjukkan bahwa edible film tersebut mudah terdegradasi dan ramah terhadap lingkungan.

Pada penelitian ini juga dapat dikembangkan dengan menggunakan variasi plasticizer seperti sorbitol. Serta dilakukan nya uji SEM (Scanning Electron Microscope) untuk mengetahui lebih detail struktur edible film berbahan kitosan, gliserol dan glukomanan. 


\section{Daftar Pustaka}

Coniwanti, P., Laila, L., \& Alfira, M. R. (2014). Pembuatan Film Plastik Biodegredabel Dari Pati Jagung Dengan Penambahan Kitosan Dan Pemplastis Gliserol. Jurnal Teknik Kimia, 20(4), 22-30.

Darni, Y., Sitorus, T. M., \& Hanif, M. (2014). Produksi Bioplastik dari Sorgum dan Selulosa Secara Termoplastik. Jurnal Rekayasa Kimia \& Lingkungan, 10(2). https://doi.org/10.23955/rkl.v10i2.2420

McHugh, T. H., Avena Bustillos, R., \& Krochta, J. M. (1993). Hydrophilic Edible Films: Modified Procedure for Water Vapor Permeability and Explanation of Thickness Effects. Journal of Food Science, 58(4), 899-903. https://doi.org/10.1111/j.1365-2621.1993.tb09387.x

Melani, A., Herawati, N., \& Kurniawan, A. F. (2017). Bioplastik Pati Umbi Talas Melalui Proses Melt Intercalation (Kajian Pengaruh Jenis Filler, Konsentrasi Filler dan Jenis Plasticiezer). Distilasi, 2(2), 53-67.

Rahmadani, S. (2019). Pemanfaatan Pati Batang Ubi Kayu dan Pati Ubi Kayu untuk Bahan Baku Alternatif Pembuatan Plastik Biodegradable. Jurnal Teknologi Kimia Unimal, 8(1), 26. https://doi.org/10.29103/jtku.v8i1.1913

Utami, M. R., \& Widiarti, N. (2014). Sintesis Plastik Biodegradable Dari Kulit Pisang Dengan Penambahan Kitosan Dan Plasticizer Gliserol. Indonesian Journal of Chemical Science, 3(2).

Yu, T., Qu, C., Fan, D., \& Xu, R. (2018). Effects of bentonite activation methods on chitosan loading capacity. Bulletin of Chemical Reaction Engineering \&amp;Amp; Catalysis, 13(1), 14-23. https://doi.org/10.9767/bcrec.13.1.1040.14-23 